that the Plan is making a real and valuable contribution to educational co-operation in the Commonwealth at a high level.

\section{Improving Britain's Overseas Technical Co-operation}

IN reply to a question in the House of Commons on January 29, the Secretary of Technical Co-operation, Mr. D. Vosper, said that he had reviewed how far Britain's overseas information met the changing needs of the day and had decided to extend the effort in three main ways. First, an increase was proposed in the British Council's English language teaching and training work, including greater use of modern methods. The Council's representation in new and developing Commonwealth and foreign countries would also be strengthened, together with some expansion in Eastern Europe. Secondly, British Information Services in some Commonwealth countries in Asia and Africa would be improved and extended. 'Thirdly, supplies of television material to the ever-growing number of stations overseas would be increased. This and other changes would involve extra expenditure of about $£ 1$ million a year. He also undertook to consider any request from an overseas Government or Governments to send teams of British journalists over. seas to conduct short training courses in developing countries if this appeared to be the most suitable way of meeting the need.

\section{Research and Development in Automation}

THE B.C.A.C. Record, 1961-62, published for tho British Conference on Automation and Computation through the Institution of Production Engineers, describes the work of the Conference during the past two years. Besidos Lord Hailsham's address to the Harrogate Conference on "Automation-Men and Money" in June 1961, it includes the text of the first two Annual Lectures: by Dr. D. C. Christopherson, "Mathematics-Friend or Foe", and by Dr. B. V. Bowden, "Automation-the Next Phase: Can Managers bo Automated ?". Prof. G. D. S. MacLellan deseribes the work of a Panel in the field of education and training, and J. E. Coales of a Panel set up to deal with research and development in automation. Copies of the Record are available from H. K. Lewis, Ltd., 136 Gower Stroot, London, W.C.1 (3s. 6d., postage paid 3s. $10 d$.)

\section{The Federal Institute of Industrial Research, Nigeria}

THe annual report for 1961-62 of the Federal Institute of Industrial Research, Nigeria, covering the initial period of establishment of the Institute, includes a review of the period 1956-62 ( $\mathrm{Pp}$. $2 \mathrm{I}+6$ plates. Lagos: Federal Ministry of Commerce and Industry, 1962. 9d.net). The Institute was established to undertake research on all Nigerian raw materials and to develop effective industrial processes by pilot- or large-scale trials if required. About two-thirds of the senior staff posts have now been filled, but less than 60 per cent of the complemont of twentyeight scientists and engineors. The major research project has been the mechanized processing of gavi, a fermented dried meal from cassava, and this has led to the successful development of a pilot-plant producing one ton a day. Other main projects in 1961-62 were on fish drying, loaf proteins, investigations on pulp and paper, solar water heating, plant gums and the utilization of cashew apple. A pilot plant producing one ton of coir fibre a day was sot up in a coconut producing aroa and is now running as a successful commercial venture.

\section{The World Health Organization International Centre for Authentic Chemical Substances}

THe function of the Centre is to assure the collection. storage and international distribution of chemical reference substances under the authority of the World Hoalth Organization. Recently, the collection of chemical sub- stances available from the Centre has boen extended by a set of thirteen substances intended for checking the accuracy of different instruments and methods for determining melting temperatures. The set of World Health Organization melting-point reference substances includes:

$\begin{array}{lrlr} & \text { M.p. } & & \text { M.p. } \\ \text { Azobenzene } & 69^{\circ} \mathrm{C} & \text { Salophen } & 192^{\circ} \mathrm{C} \\ \text { Vanillin } & 83^{\circ} \mathrm{C} & \text { Sulphapyridine } & 193^{\circ} \mathrm{C} \\ \text { Benzil } & 96^{\circ} \mathrm{C} & \text { Dicyandiamide } & 210^{\circ} \mathrm{C} \\ \text { Acetanilide } & 116^{\circ} \mathrm{C} & \text { Saccharin } & 229^{\circ} \mathrm{C} \\ \text { Phenacetin } & 136^{\circ} \mathrm{C} & \text { Caffeine } & 237^{\circ} \mathrm{C} \\ \text { Benzanilide } & 165^{\circ} \mathrm{C} & \text { Phenolphthalein } & 263^{\circ} \mathrm{C} \\ \text { Sulphanilamide } & 166^{\circ} \mathrm{C} & & \end{array}$

The substances are availablo in a polystyreno plastic package together with a leaflet on "Directions for Use". The following authentic chemical substances are also available:

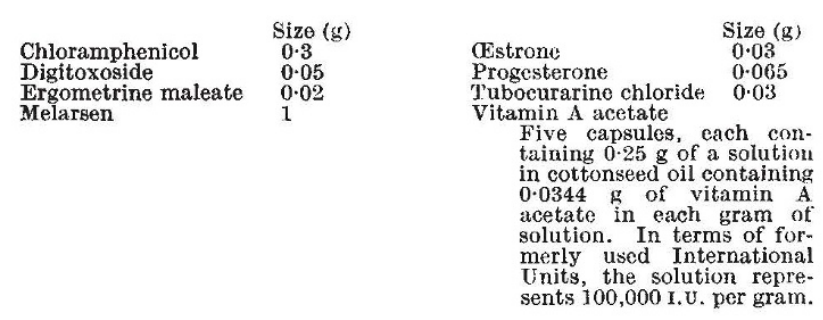

All the substances are sent free of charge to national administrations or laboratories and institutes working on a non-profit basis. Commercial laboratories are charged 10 dollars (U.S.) or the equivalent amount in other currency per set of melting-point reference substances and 4 dollars (U.S.) per package of the other substances. Orders for the substancos should be sent to: WHO International Centre for Authentic Chemical Substances. Apotekens kontrollaboratorium, Box 30019, Stockholm 30. During 1963 the following substances are expected to be issued as authentic chemical substances: cortisone acetate, deoxycorticosterone acetate, dienœstrol, diethylstilbcestrol, œstradiol benzoate, ethinyl œstradiol, ethisterone, hydrocortisone, hydrocortisone acetate, liothyronine, methyltestosterone, prednisolone, prednisone and testosterone propionate.

\section{The Zoological Society of London :}

Awards

THE following awards of the Zoological Society of London will be presentod by H.R.H. The Duke of Edinburgh, president of the Society, at the annual general meeting on May 16: Scientific Medal, to Dr. J. W. L. Beament, of the Department of Zoology, University of Cambridge, for his outstanding work on the detailed physical and chemical study of the insect cuticle and egg shell and the discovery of important general principles concerning water conservation in small terrestrial mammals; and to Dr. N. A. Mitchison, of the National Institute for Medical Research, for his outstanding work on immunology and tissue transplantation; Stamford Raffles Award, to Mr. R. E. Moreau, in recognition of his contributions to zoology - as an amateur zoologist, Mr. Moreau has acquired an international reputation as an authority on the birds of Africa; Thomas Henry Huxley Award, to Dr. J. Machin, of Queen Mary College, now working at the University of Toronto, for original work submitted as a Ph.D. thesis to the University of London on "The Water Relations of Snail Integument"; Prince Philip Prize (open for competition to pupils of zoology, taking the Genoral Certificate of Education Advancod-Level or equivalent examination in any school in Great Britain, Northern Ireland and the Channel Isles and Isle of Man), to Wondy A. Froaker, of St. Swithun's School, Winchester, for her ontry, "An Investigation into the Casing Habits of the Caddis-fly Larva, Limnophilus vittatus". 